Acta regionalia et environmentalica 2

Nitra, Slovaca Universitas Agriculturae Nitriae, 2013, p. 55-58

\title{
EVALUATION OF DRY MATTER PRODUCTION OF MISCANTHUS SINENSIS (TATAI) IN THE CONDITIONS OF SOUTH-WESTERN SLOVAKIA
}

\author{
Martin PRČ́́K, Marián KOTRLA \\ Slovak University of Agriculture in Nitra, Slovakia
}

\begin{abstract}
In this paper, we present the results of research of phytomass production allocated to aboveground organs, leaves and stalks, after the third growing year. The research was conducted in the field experiment conditions of Farm holding in Kolínany. The results of the aboveground dry matter production are expressed in tonnes of dry weight produced on the area of one hectare $\left(t . h a^{-1}\right)$. The

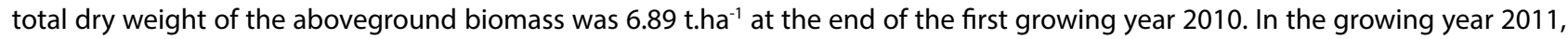
it reached 15.21 t.ha $^{-1}$ (an increase by $121 \%$.) The total dry weight of the aboveground phytomass increased by $37 \%$ compared to 2011, and it reached 20.82 t.ha $^{-1}$ in the third growing year (2012). The increase of phytomass is directly proportional to off shoot circle. Average off shoot circle of individuals in the first growing year was $300 \mathrm{~mm}$ and the average number of stems produced in a clump was 37.60. In 2011, the average off shoot circle of individuals was $502 \mathrm{~mm}$ and there were 43.73 stems created in a clump. In the third growing period of 2013, the extension of the off shoot circle by $113.7 \%(641 \mathrm{~mm})$ was registered in comparison with 2010 and the amount of 80.19 stems per clump was recorded.
\end{abstract}

Keywords: Miscanthus sinensis (Tatai), phytomass, dry matter, off shoot circle, south-western Slovakia

Intensive cultivation of energy plants in Slovak conditions has not yet had a long tradition. Most of these plants are little known, however, many of these species were grown in our region in the past. One group of energy plants are energy grasses, which include Miscanthus sinensis (Jandačka and Malcho, 2007). Biomass has the largest share of technically usable potential of renewable energy sources. At present, biomass is utilized for approximately one third.

The production of biomass on the agricultural soils and its use for energy purposes can actively contribute to commitments of Slovakia to ensure $12 \%$ of energy from renewable sources by 2020 .

A large number of plant species can be used for combustion (Hofbauer, 2009). In order to be economically efficient, the annual yield of dry matter of energy crops should be around $12 \mathrm{t} \mathrm{ha}^{-1}$, while perennial energy crops require fertilization.

Growing energy crops on agricultural land creates an opportunity for the use of the areas that are less suitable for growing traditional field crops. The energy crops provide permanent soil cover and their further utilization may also contribute to the improvement of energy and economic balance of the agricultural system (Pospišil and Vilček, 2000).

The ecological value of energy plantations depends to a significant extent on the country context, the size of the cultivation area, and specific regulatory measures. According to Weih et al. (2003), the size of the agricultural land is a crucial factor. The biodiversity increase in agricultural landscape was confirmed also on smaller plantations of fast-growing willows and poplars.

In the conditions of Europe, the plants are capable to create 1.2 to $1.4 \mathrm{~g}$ of dry phytomass from $1 \mathrm{MJ}$ of solar energy. The plants that use C4 photosynthetic pathway are more efficient. The creation of $1.4 \mathrm{~g}$ of dry weight from $1 \mathrm{MJ}$ of solar energy is considered as one of the criteria for selection of plants for phytoenergetic purposes (Jandačka et al., 2011).

The aim of this paper is to evaluate the production of dry matter of Miscanthus sinensis (Tatai) and its allocation to above-ground organs in terms of south-western Slovakia. In this paper, we focus on the relationship between the phytomass increase and size change of off shoot circle of the individuals.

\section{Material and methods}

\section{Characteristics of the research base}

The research was conducted on a field trial base of the Farm holding of Slovak University of Agriculture in Kolíňany. The research area in Kolíňany is located $13 \mathrm{~km}$ from the city of Nitra. The soil quality defined by BSEU code is 0111002 . The main soil unit is gley fluvisol, in terms of grain structure it belongs to moderately heavy soils. In terms of exposure, this area is plain without an expression of surface erosion $\left(0^{\circ}\right.$ to $1^{\circ}$ ). Soils are deep ( $60 \mathrm{~cm}$ or more) without skeleton. In terms of climatic conditions, the research area belongs to a warm, very dry, lowland climate region.

\section{Organization of experiment and plant material}

The experiment was established in 2010. The plants were planted in the planting distance $1 \times 1 \mathrm{~m}$ on the area of $100 \mathrm{~m}^{2}$. Seedlings of the Miscanthus sinensis (Tatai) grown by multiplication of biological material in vitro (meristematic tissues) were used. Genus Miscanthus occurs naturally mainly in tropical and temperate regions. The genus Miscanthus is covered in total of 33 taxes. Miscanthus is a perennial $C_{4}$ plant (Strašil, 2012). In our research, triploid hybrid (57 chromosomes) of Miscanthus sinensis (Tatai), was used. It was bred by cross pollination of Miscanthus 
sinensis genotypes. Seedlings grown by in vitro techniques in Power-H Kft. in Hungary were used as a planting material. Seedlings with already developed rootsystem were planted individually (Jureková et al., 2012).

Nowadays in Slovakia, it is grown on soils ranging from loamy-sandy to loamy, moderately heavy soils, with an average annual temperature of $9{ }^{\circ} \mathrm{C}$. Thus, suitable areas can be found in southern Slovakia, the Danube Lowland, the Eastern Slovak Lowland and part of Záhorie (Porvaz, 2006). Optimal soil pH ranges from 5.5 to 6.5. A decrease of yield was observed on a soil with $\mathrm{pH}$ of more than 7.0. Transpiration coefficient is around $250 \mathrm{I} \mathrm{kg}^{-1}$ of dry matter, which means that the crop uses water efficiently (Strašil, 2009).

\section{Monitored indicators}

At the end of the first, second and third year of the growing period, the phytomass allocated to the individual organs aboveground organs (leaves and stems) was studied. The collection of the aboveground phytomass samples was carried out in March of the next year after each growing year. Fresh weight was determined (at harvest humidity) and afterwards, the individual aboveground organs were oven-dried at $105{ }^{\circ} \mathrm{C}$. After the drying, the weight of the aboveground dry matter was determined.

Gradual change of aboveground dry matter weight and the average number of stems formed on one clump in dependence of the size change of off shoot circle was monitored. Off shoot circle size was determined during the growing period as the average size of the circle.

Statistical evaluation was processed in the statistical package STATISTICA 10. ANOVA and statistically significant differences tested by Scheffe's test were used for the analysis of the monitored variables in different years.

\section{Results and discussion}

The formation of biomass of the studied plants and its allocation to individual aboveground organs (particularly leaves and stems) were observed at the end of the first growing year 2010. The percentage of the well-rooted plants was $100 \%$ and already in the first growing year, the planted individuals created a good canopy closure. The results of phytomass yields were not influenced by any drop out of plants, or extreme weather conditions in the given year.
Clifton-Brown and Lewandowski (2002) presented results from field trials with different genotypes of Miscanthus. Kaack and Schwarcz (2001) studied the impact of several factors such as harvest period, lodging, pruning, fertilization and mechanical and morphological properties of plants.

As can be seen from the figures presented in Table 1, the production of dry leaves was $185 \mathrm{~g} \mathrm{clump}^{-1}$ and dry matter of stems was $385 \mathrm{~g} \mathrm{clump}^{-1}$ at the end of the first growing year 2010. The total production of the aboveground dry matter was $570 \mathrm{~g} \mathrm{clump}^{-1}$. The total production of the dry matter of the aboveground organs, based on the planting distance, represents $6.89 \mathrm{t} \mathrm{ha}^{-1}$. The average size of the off shoot circle was $300 \mathrm{~mm}$ at the end of the first growing year.

Table 1 Average values of dry matter of the aboveground organs of Miscanthus sinensis (Tatai) in different growing years in g clump $^{-1}$

\begin{tabular}{|l||c|c|c|}
\hline \multirow{2}{*}{$\begin{array}{l}\text { Aboveground } \\
\text { organs }\end{array}$} & \multicolumn{3}{|c|}{ Growing period - year } \\
\cline { 2 - 4 } & $\mathbf{2 0 1 0}$ & $\mathbf{2 0 1 1}$ & $\mathbf{2 0 1 2}$ \\
\hline \hline Leaves & 185 & 492 & 750 \\
\hline Stems & 385 & 765 & 970 \\
\hline Total & 570 & 1257 & 1720 \\
\hline
\end{tabular}

Dry matter production of leaves was $492 \mathrm{~g} \mathrm{clump}^{-1}$ and stems $765 \mathrm{~g} \mathrm{clump}^{-1}$ at the end of the second growing year (2011). The total dry matter of the aboveground organs, based on the planting distance was $15.21 \mathrm{t} \mathrm{ha}^{-1}$. It is an increase of $121 \%$ compared to the first year. The average size of the off shoot circle was $502 \mathrm{~mm}$ (an increase in size by $67 \%$ ) at the end of the second growing season.

The production of dry matter of leaves was $750 \mathrm{~g} \mathrm{clump}^{-1}$ and stems 970 g clump $^{-1}$ at the end of the third growing year (2012). The total dry matter increase per 1 clump is $202 \%$ compared to the first year. The dry matter yield increased by $37 \%$ in comparison with the second year. The total dry matter production of the aboveground organs was 20.82 $\mathrm{t} \mathrm{ha}^{-1}$ based on the planting distance. Compared to other vegetation years, this is an increase of the dry matter by $37 \%$ per one hectare. The average size of the off shoot circle was $641 \mathrm{~mm}$ at the end of the third growing season, which is an increase in size by $113 \%$ compared to the first year. The increase of the average size of the off shoot circle between the second and the third year is $28 \%$.

Table 2 ANOVA and Scheffe's test of dry weight of Miscanthus sinensis (Tatai)

\begin{tabular}{|c|c|c|c|c|c|}
\hline \multicolumn{6}{|c|}{ Analysis of variance $p<0.05000$} \\
\hline & Sum of squares & Degree of freedom & Mean squares & $\mathbf{F}$ & $\mathbf{p}$ \\
\hline Dry weight & 15709597.4 & 2 & 7854798.72 & 772.81754 & $0.0000(++)$ \\
\hline \multicolumn{6}{|c|}{ Scheffe's test; variable: dry weight $p<0.01000$} \\
\hline \multirow{2}{*}{\multicolumn{2}{|c|}{$2010\{1\}$}} & & $\{2\}-M=1154.4$ & $\multicolumn{2}{|c|}{3}-M=1580.4$ \\
\hline & & & $4.15548815 \mathrm{E}-27$ & \multicolumn{2}{|c|}{0} \\
\hline \multicolumn{2}{|l|}{$2011\{2\}$} & $3815 \mathrm{E}-27$ & & \multicolumn{2}{|c|}{ 8.64288707E-14 } \\
\hline $2012\{3\}$ & \multicolumn{2}{|c|}{0} & 8.64288707E-14 & & \\
\hline
\end{tabular}




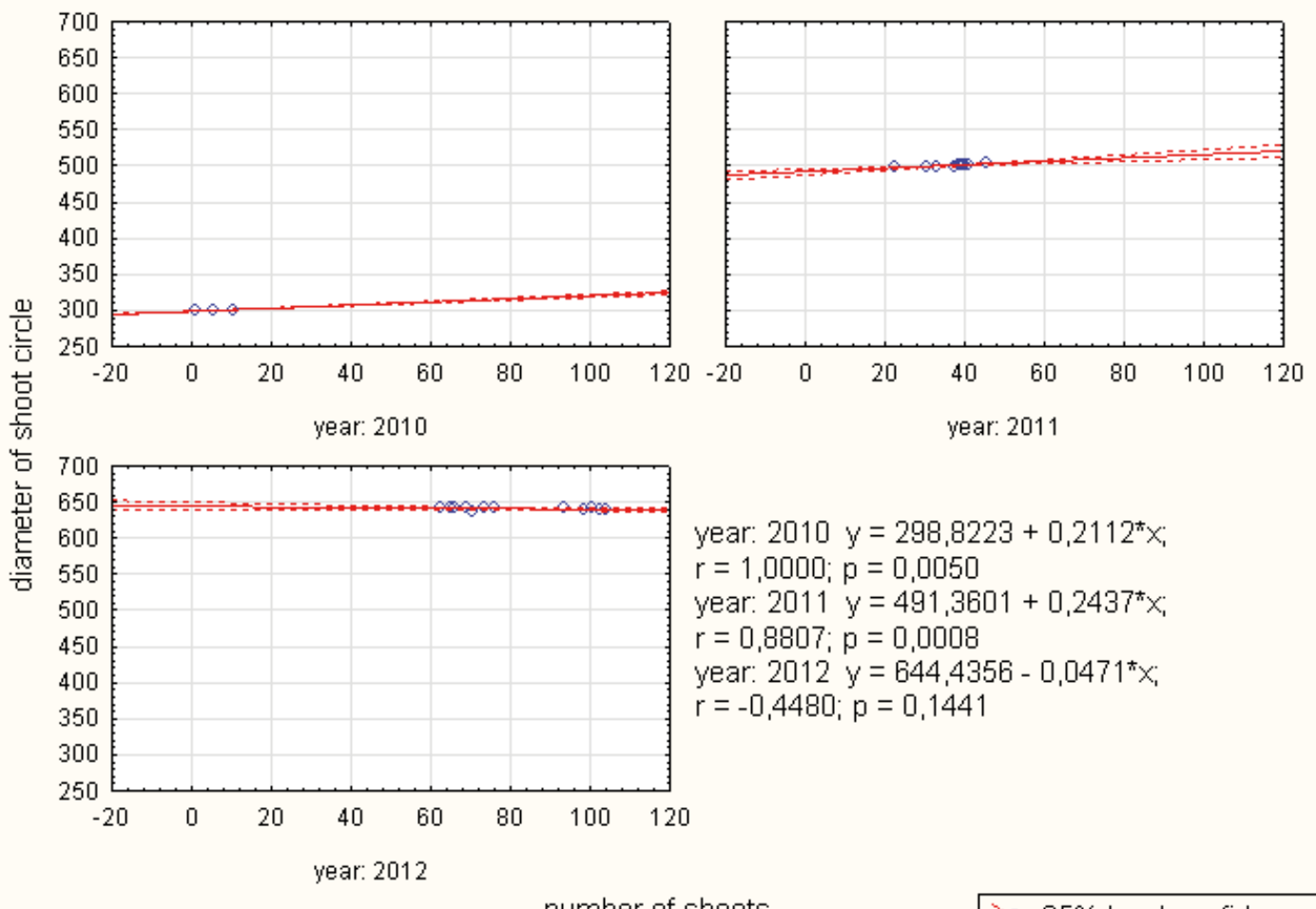

number of shoots

Q. $95 \%$ level confidence

Figure 1 The dependence of the diameter of the off shoot circle on the number of shoots

The average dry matter yield of the aboveground phytomass of Miscanthus sinensis (Tatai) had an increasing trend. The differences among the studied years were statistically highly significant (Table 2). This significance and increasing trend in aboveground phytomass yields were confirmed also by Porvaz, Tóth and Marcin (2012). They

Table 3 The average number of stems formed in one clump of Miscanthus sinensis (Tatai) and the average size of the off shoot circle

\begin{tabular}{|l||c|c|c|}
\hline \multicolumn{1}{|c||}{} & \multicolumn{3}{c|}{ Growing period - year } \\
\cline { 2 - 4 } & $\mathbf{2 0 1 0}$ & $\mathbf{2 0 1 1}$ & $\mathbf{2 0 1 2}$ \\
\hline \hline Number of stems on the clump & 37.60 & 43.73 & 80.19 \\
\hline Average off shoot circle in $\mathrm{mm}$ & 300 & 502 & 641 \\
\hline
\end{tabular}

observed the production of dry matter and size of the off shoot circle of Miscanthus in the Eastern Slovak Lowland conditions.

Individual living space is an important factor in terms of phytomass production because it affects the gradual growth of underground organs and occupation of the living space. It relates to competition for light conditions and energy in the form of water and nutrients, and thus supports a gradual increase of the aboveground phytomass.

At the end of the first growing year (2010), one plant produced on average 37.60 stems in the shape of a circle with a diameter of $300 \mathrm{~mm}$. The average number of stems increased to 43.73 and the size of the stem circle reached a diameter of $502 \mathrm{~mm}$ at the end of the second growing year. The number of stems increased by $16 \%$ compared with the first year. At the end of the third growing year (2012),

Table 4 ANOVA and Scheffe test of the average number of stems and diameter of the off shoot circle of Miscanthus sinenesis (Tatai)

\begin{tabular}{|l||c|c|c|c|c|}
\hline \multicolumn{7}{|c|}{ Analysis of variance $\boldsymbol{p}<\mathbf{0 . 0 5 0 0 0}$} \\
\hline & Sum of squares & Degree of freedom & Mean squares & F & p \\
\hline \hline Number of stems & 19260.4 & 2 & 9630.2 & 62.55 & $0.0000(++)$ \\
\hline Diameter of off shoot circle & 309150.2 & 2 & 154575.1 & 17350.27 & $0.0000(++)$ \\
\hline
\end{tabular}

\begin{tabular}{|l||c|c|c|}
\hline \multicolumn{4}{|c|}{ Scheffe's test; variable: number of stems $\boldsymbol{p}<\mathbf{0 . 0 1 0 0 0}$} \\
\hline & $\{\mathbf{1}\}-\boldsymbol{M}=\mathbf{5 . 5 7 6 7}$ & $\{\mathbf{2}\}-\boldsymbol{M}=\mathbf{3 6 . 6 8 2}$ & $\{\mathbf{3}\}-\boldsymbol{M}=\mathbf{8 1 . 7 4 2}$ \\
\hline \hline $2010\{1\}$ & & 0.003811 & 0.000000 \\
\hline $2011\{2\}$ & 0.003811 & & 0.000000 \\
\hline $2012\{3\}$ & 0.000000 & 0.000000 & \\
\hline
\end{tabular}

\begin{tabular}{|l||c|c|c|}
\hline \multicolumn{3}{|c|}{ Scheffe's test; variable.: diameter of shoot circle $\boldsymbol{p}<\mathbf{0 . 0 1 0 0 0}$} \\
\hline & $\{\mathbf{1}\}-\boldsymbol{M}=\mathbf{3 0 0 . 0 0}$ & $\{\mathbf{2}\}-\boldsymbol{M}=\mathbf{5 0 2 . 0 0}$ & $\{\mathbf{3}\}-\boldsymbol{M}=\mathbf{6 4 1 . 0 0}$ \\
\hline \hline $2010\{1\}$ & & $3.10596290 \mathrm{E}-30$ & 0 \\
\hline $2011\{2\}$ & $3.10596290 \mathrm{E}-30$ & & 0 \\
\hline $2012\{3\}$ & 0 & 0 & \\
\hline
\end{tabular}


there was a further gradual increase in the average number of stems produced in one clump to 80.19 stems. The average number of stems increased by $113 \%$ compared to the first growing year. The average number of stems increased by $83 \%$ between 2011 and 2012. The average size of the off shoot circle was $641 \mathrm{~mm}$ in the third growing year (Table 3).

Comparable average size of the off shoot circle of Miscanthus grown in the Eastern Slovak Lowland was achieved in the second growing year $(610 \mathrm{~mm})$. The average size of the off shoot circle in the Eastern Slovak Lowland was $810 \mathrm{~mm}$ at the end of the fourth crop year (Porvaz, Tóth and Marcin, 2012).

The differences in the average number of shoots and sizes of the off shoot circle were statistically highly significant in the surveyed years (Table 4). The dependence of off shoot circle diameter on the stem growth was statistically significant (significance level $\alpha=0.05$ ) only in 2010 and 2011 (Figure 1). In terms of phytomass production, the year 2012 is the third growing cycle of Miscanthus sinensis (Tatai), which is characterized by high phytomass yields of the aboveground organs. The correlation was not confirmed in $2012(r=-0.4480)$. This reflects the increase and subsequent drying up of stems from the centre of the clump from the time of stem growth culmination (June - July) until the end of the growing season. This course represents an overall effect of the competition among stems for environmental conditions, especially light.

\section{Conclusion}

Constantly increasing values of the dry matter of the studied plants of Miscanthus sinensis (Tatai) confirmed that the plants were able to adapt to the climate area, and the potential of this crop in the climatic conditions of the Slovak Republic can be used in practice. Miscanthus sinensis (Tatai) developed full canopy closure in the first growing year, which enabled us to use the full efficiency of the potential of all studied plants within the research site. The amount of the dry matter formed in cultivation years 2010 to 2012 represents an economically relevant level at which it is possible to use the biomass of Miscanthus sinensis (Tatai) for energy purposes. This is influenced by the fact that Miscanthus sinensis (Tatai) belongs to the group of C4 plants that are able to use solar energy more efficiently. The ability of the species to expand into the space vegetatively was confirmed. This fact positively affected the gradual increase and allocation of organic matter in the aboveground organs (leaves and stems).

\section{Acknowledgment}

This work was supported by the Slovak Grant Agency for Sciences (VEGA) Grant No. 1/1220/12 and Grant No. 1/0942/12.

\section{References}

CLIFTON-BROWN, J. C. - LEWANDOWSKI, I. 2002. Screening Miscanthus genotypes in field trials to optimise yield and quality in Southern Germany. In European Journal of Agronomy, no. 16, pp. 97-110. ISSN 1161-0301.

HOFBAUER, J. 2009. Možnosti energetického využití netradičních plodin. In Biom. Cz. [online] [cit. 2013-05-24]. Dostupné na internete: http://biom.cz/cz-pestovani-biomasy/ odborne-clanky

JANDAČKA, J. - MALCHO, M. 2007. Biomasa ako zdroj energie potenciál, druhy, bilancia a vlastnosti palív. Žilina : Žilinská univerzita. 78 s. ISBN 80-969161-4-6.

JANDAČKA, J. - NOSEK, R. - KADUCHOVÁ, K. - KOLKOVÁ, Z. 2011. Využitie rastlinnej biomasy $v$ energetike. Žilina : Juraj Štefun-Georg. 120 s. ISBN 978-8089401-39-0.

JUREKOVÁ, Z. - KOTRLA, M. - PAUKOVÁ, Ž. - PRČíK, M. 2012. The growth and yield of different Miscanthus genotypes in the conditions of south-western Slovakia. In: Acta regionalia et environmentalica, 2012 no. 2, pp. 29-34. ISSN 1336-5452

KAACK, K. - SCHWARCZ, K. U. 2001. Morphological and mechanical properties of Miscanthus in relation to harvesting, lodging, and growth conditions. In Industrial Crops and Products, no. 14, pp. 145-154. ISSN 0926-6690.

PORVAZ, P. 2006. Production parameters of Miscanthus sinensis $A$. in the conditions of the East Slovakian Lowland. In Biotechnology 2006. České Budějovice : Scientific Pedagogical Publishing. pp. 506-509. ISBN 808-5645-53-X.

PORVAZ, P. - TÓTH, Š. - MARCIN, A. 2012. Cultivation of chinese silvergrass (Miscanthus sinensis Andress.) on the Slovak lowlandas a potential source of raw material for energy purposes. In Agriculture, vol. 58, 2012, no. 4, pp. 146-153. ISSN 0551-3677.

POSPIŠIL, R. - VILČEK, J. 2000. Energetika sústav hospodárenia na pôde. Bratislava : VÚPOP. 108 s. ISBN 80-85361-75-2.

STRAŠIL, Z. 2009. Základy pěstování a možnosti využití ozdobnice (Miscanthus) : metodika pro praxi. Praha : VúRV. $48 \mathrm{~s}$. ISBN 978-80-7427-006-2.

STRAŠIL, Z. 2012. Pěstování ozdobnice (Miscanthus $\times$ giganteus) určené pro energetické využití. In Úroda. Aktuální poznatky v péstování, šlechtení, ochran ěrostlin a zpracován íproduktů, roč. 60, 2012, č. 12, s. 97-102. ISSN 0139-6013.

WEIH, M. et al. 2003. Influence of young poplar stands on floristic diversity in agricultural landscape (Sweden). In Basic and Applied Ecology, vol. 4, 2003, pp. 149-156. ISSN 1439-1791.

\section{Contact address:}

Ing. Martin Prčík, PhD., Slovak University of Agriculture in Nitra, Faculty of European Studies and Regional Development, Department of Sustainable Development, Mariánska 10, 94901 Nitra, phone: +421 3764156 28, e-mail: martin.prcik@uniag.sk 